\title{
GRUPOS INTERATIVOS DE APRENDIZAGEM: UMA EXPERIÊNCIA COM ALUNOS DO ENSINO MÉDIO
}

\author{
Thiago Brandão Ericeira ${ }^{\mathrm{a} *}$; Edu Celso Pereira ${ }^{\mathrm{a}}$; Raimundo Luna Neres ${ }^{\mathrm{a}}$ \\ ${ }^{a}$ Centro Educa Mais Força Aerea Brasileira. R. do Arame, 88, São Cristovao, São Luís, MA, Brasil. \\ *E-mail para correspondência: thiagobrandao08@hotmail.com
}

\section{Palavras-chave: \\ Centro Educa Mais; Interatividade; Matemática.}

\section{Keyworda}

Education Center; Interactivity; Mathematics.
O professor é quem cria as oportunidades para a aprendizagem. Seja na escolha de atividades significativas e desafiadoras para seus alunos, seja na gestão de sala de aula. Assim, aplicamos os Grupos Interativos no processo de ensino e aprendizagem dos nossos alunos do Ensino Médio em um Centro Educa Mais na disciplina de Matemática.

Esta metodologia é uma forma de organização que proporciona os melhores resultados no desenvolvimento das atividades nas aulas de Matemática quanto à melhora na aprendizagem no convívio dos alunos é por meio dos grupos interativos em sala de aula. Por meio deles, as interações dos alunos se multiplicam, se diversificam, e o tempo de trabalho efetivo se expande.

Esse tipo de organização inclui todos os estudantes, e necessita do apoio de outros sujeitos da comunidade escolar (pais, agente administrativos, outros professores e amigos da escola) além do professor aplicador. O objetivo em utilizar os grupos interativos é desenvolver, em uma mesma dinâmica, a aceleração da aprendizagem para todos, além de valores e sentimentos. Essas interações dialógicas possibilitaram que os alunos aprendessem a realizar tarefas que ainda não possuíam autonomia, mas estavam em vias de fazer sozinho.

A experiência foi realizada pelo primeiro autor (gestor da unidade escolar) que observou as aulas do segundo autor (professor), em uma escola estadual de tempo integral denominado "Educa Mais" no estado do Maranhão, em uma turma com 40 alunos durante a aula de Matemática. Segundo Lev Vygotsky, os Grupos Interativos atuam na Zona de Desenvolvimento Proximal dos alunos, ampliando assim, sua área de desenvolvimento real.

O professor responsável pelo componente curricular (Matemática) dividiu a turma em seis grupos, com seis a sete alunos cada, os critérios para a construção

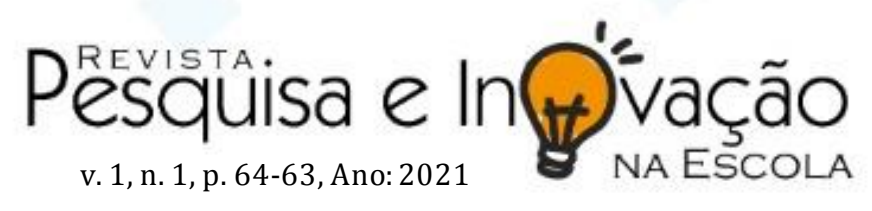


dos grupos foi a heterogeneidade: níveis de aprendizagem diferentes, sexo, cor e cultura. Cada grupo teve seu voluntário com papel estratégico no processo, que foi garantir a interação, dinamismo e o foco no desenvolvimento das atividades com interatividade entre os membros. Cada voluntário passou por todos os grupos, proporcionando um rodízio de atividades com duração aproximada de vinte minutos. O professor aplicador (Matemática) passava em todos os grupos para apoiar os voluntários e tirar as possíveis dúvidas dos alunos. No final do ciclo de atividades, os grupos participantes reúnem-se para avaliação dos seus respectivos papeis e com o foco na interatividade proporcionada pela formação dos grupos.

A experiência realizada nos revelou que essa estratégia de trabalho em sala de aula pode auxiliar os professores e gestores, principalmente o pedagógico de maneira significativa, pois indica as potencialidades dos indicadores de proficiência da unidade escolar, além de criar um elo entre família e escolas, o que facilita o envolvimento dos alunos no desenvolvimento de suas atividades escolares. A experiência também nos proporcionou observar que essa estratégia de aprendizagem contribuiu na conscientização da comunidade escolar no caminho da criação de sentindo e transformação dos nossos alunos nos aspectos de sua formação para vida em jovens solidários, autônomos e competentes. Vale destacar que as atividades propostas foram com conteúdo já discutidos e sala pelo professor. 